\title{
PIK3R1 wt Allele
}

National Cancer Institute

\section{Source}

National Cancer Institute. PIK3R1 wt Allele. NCI Thesaurus. Code C97734.

Human PIK3R1 wild-type allele is located in the vicinity of $5 q 13.1$ and is approximately 86 $\mathrm{kb}$ in length. This allele, which encodes phosphatidylinositol 3-kinase regulatory subunit alpha protein, plays a role in the regulation of second messenger phosphorylation. 